\title{
Factors Influencing Family Size: A Critical Study on Khulna District of Bangladesh
}

\author{
Md. Jahidul Islam*
}

Sociology Discipline, Social Science School, Khulna University, Khulna, Bangladesh.

*Correspondence: jahidsoc14ku@gmail.com

\begin{abstract}
Family size in any particular society depends on different socioeconomic and cultural factors. This study makes an attempt to examine the determinants of family size in the Khulna district of Bangladesh. The study was carried out in Paikgacha villages under Paikgacha upazilla and. Ward no. 31 of Khulna city under Khulna district. The study opted for survey research design and the unit of analyses was the head of households from the study area. Samples of 296 respondents were selected through simple random sampling and were interviewed with a semi-structured interview schedule. The bivariate studies were executed using chi-square to explore the probable association between family size and certain covariates. To know the marginal effects of independent variables, the OLS (Ordinary Least Square) model was measured. Results show that half of the households ( $54.1 \%$ to be exact) were small (had four or less than that members) in size. Besides, age, family income, educational status, number of surviving children, number of desired children, sex preferences, contraceptive use, family planning, and residence were linked with the size of the family $(\mathrm{p}<.005)$ as potential socioeconomic and cultural factors.
\end{abstract}

Keywords: Family size, Socio-economic, Cultural, Sex preference, Family planning, and Determinants, etc.

\section{INTRODUCTION:}

The size of the family is a thing of great importance not only for the country as a whole, but also for the well-being and health of the respected person, the family and the community (Arthur, 2005; Hyeladi \& Alfred, 2014). Besides, Family extent and composition in a community, in particular depends on the familial, cultural system, socioeconomic consequences of the planned couples who are going to form a family or the eligible couples who are living in the family (Uddin et al., 2012). Hence, family size is the number of family members, including children irrespective of wherever they live (Jones, 2005). Simply, it can be declared that the association patterns of the family: marriage, blood, and approvals which are favored by family, cultural structure and vary from one community or society to another define the family size. The inclination of UniversePG I www.universepg.com family sizes and its tendency for a probable world population explosion can rush poor developing countries into further poverty and helpless grief, Traditional attitudes of women's role in society make it challenging for them to contribute to population control (Arthur, 2009; Jones, 2005). Another study found that family size indicates the total number of children a woman has carried at a point in a given time. Family size depends on numerous factors, such as age, duration of marriage, literacy, preference of the number of children, etc (Ojha, 1999). Existing literature suggests that the continuing increase in the world population has become an urgent global problem. Most of this growth is happening in developing countries where the deterioration in the total fecundity rate is slow. The deliberate decline of the total fecundity rate may be not up to the mark because the population has not 
transferred their desired family size (Walle, 1992; Hagen et al.,1999). Another study affirmed that variables indicating family extent are firm predictors of the number of children born to women (Bhargava, 2007).

Bangladesh is a country where familial, social, economic, and religious conditions are highly favorable to the preference for sons (Parvez et al., 2019). Another study shows that traditionally parents desire great families because children are considered highly for their contribution to food stock and other family activities (Arnold, 1985). Many studies have found that couples represented a decided favor for having children of a particular gender. Preferences for son is accepted in many developing countries, especially these in South Asia, but a preference for balanced number of daughters and sons is also common (Arnold, 1987; Cleland et al., 1983). Even where son preference is strong, couples usually reveal a passion to have at least one child of each sex (Arnold, 1991). A strong preference for son could be a vital obstacle to perform family planning if couples who have already transferred their desired family size continue child bearing to attempt for a child of the preferred sex (Nag, 1991). The decision to have a large family size and timing is critical issue that may involve a trade-off of the family's rare incomes against a large family size (Hyeladi \& Alfred, 2014).

Furthermore, Kpakpor, (2005) claimed that in most of the cases the people with large family size were illiterates. He further emphasized that a family of about twenty members would reasonably have a poverty rate of 90 percent. In general, it is asserted that there is an implication of an increase in poverty predominance as family size increases. A study has shown that without the knowledge of factors affecting family size, the desire to achieve small family size and harmonize the rate of population growth with socioeconomic improvement to reach a high level of welfare cannot be achieved (Aigbokhan, 2008).

Trends in family shaped favor have important implications for trends in fertility (Koenig et al., 2013). The high and nearly stable desired family size is a hindrance to further fertility decline. Both sociologists and anthropologists claim that every couple in a society has an ideality of family size and structure calculated by the family, cultural system, socio-cultural state outcomes (Uddin et al., 2012). UniversePG I www.universepg.com
According to modal family size and structure, each couple demands a number of family members and fulfills their demand for children to involve in actual reproductive behavior (Maloney et al., 1981). Another study found that education levels of women and husbands are indicated to be inversely related to the ideal and desired family size in both urban and rural areas (Ali, 1989). Given the context, this study tried to find the socioeconomic determinants of affecting the family pattern and the changes in the effects of these factors over time in the Khulna district of Bangladesh.

\section{MATERIAL AND METHODS:}

This study is a cross-sectional research work conducted at ward no. 31 and 05at the Shipyard included in the Khulna City Corporation and Paikgacha village under the Sholadana Union of Paikgacha Upazilla in the same District. Survey research design was followed in this study and a total of 296 respondents from the head of the household and permanent inhabitants in the selected study areas. The respondents were selected by using simple random sampling technique after a census conducted in the selected areas. 24 respondents either could not either be reached or decided not to participate in this study. The response rate for this study was $92 \%$. A thorough review of relevant literature was done in preparing the interview schedule used in this study. We included a total of 41 items in the interview schedule and pre-tested it on 20 respondents before the final data collection. The collected data during the month of February to March, 2019 with face-toface interviews. Collected data were organized and resolved through SPSS version 21 software.

The principal ordinal dependent variable, determinants of family size, was categorized as 'Small' and 'Large'. The bivariate analyses were accomplished using the chi-square test to examine possible associations between Family size and selected covariates to know the marginal effects of independent variables. For ethical clearance, we acquired both written and verbal consent from the participants in this study and followed a strict standard of protecting their privacy. The participants were informed that participation in this study is voluntary and they had the freedom to terminate themselves from the interview process if they wished. 
Table 1: Variable List for the Study.

\begin{tabular}{|c|c|c|c|}
\hline Variables & Unity of meas & Related Reference & ES \\
\hline Education & In Years & Dibaba and Mitike, 2016 \\
\hline Residence & $0=$ urban, 1= Rural & Uddin et al., 2011 \\
\hline Family Income & BDT/Month & Becker, 1991; Sharif et al., 2007) & + \\
\hline Religion & 1=Muslim,2=Non-Muslim & Maleche, 1990) \\
\hline Sex Preference & $0=$ Yes, 1=No & Egero and Hammarkjold, 1994); Nag, 1991 & + \\
\hline Age at marriage & In Years & Campbells, 1986 & - \\
\hline Number of living children & Number & Ali, 1989 \\
\hline
\end{tabular}

Source: Authors' compilation, 2019

\section{RESULTS:}

The demographic and Socioeconomic characteristics of the respondents shows in Table 2. It is found that the majority (39.5\%) of the respondents is in the age group of $\leq 30$ years. In this study revealed that most of the respondents $(50.0 \%)$ were those who were married up to 18 years and only $15.2 \%$ of the respondents were married up-to the age of 24 years. the majority of the respondents $(37.5 \%)$ were attained primary level of education. In this study (45.6\%) of the respondents were belonged to Urban area and 54.4 percent was rural area and Income level of $37.2 \%$ respondent's family income was 10001-20000 per month from all sources. The data indicate that $54.1 \%$ respondent's family members were in the group of four and less than four which explore that most of the respondents belongs to small families size and majority of the respondents $(52.0 \%)$ were number of living up to two children. This study noted that $(55.7 \%)$ respondents were desired up to two numbers of children and The study shows that majority $(86.1 \%)$ of the respondents have sex preferences. Besides, majority $(55.7 \%)$ of the respondents have awareness regarding contraception before sexual engagement. Moreover, the $(56.8 \%)$ of the respondents reported that they have decision of family planning.

Table 2: Demographic and Socio-economic Information of the Respondents.

\begin{tabular}{|c|c|c|c|}
\hline Age (In year) & & Frequency & Percent \\
\hline & $\leq 30$ & 117 & 39.5 \\
\hline & $31-40$ & 101 & 26.4 \\
\hline Age at first marriage(In year) & $\geq 41$ & 78 & 40.5 \\
\hline & $\leq 18$ & 120 & 31.1 \\
\hline & $19-23$ & 92 & 28.4 \\
\hline Educational Status & $\geq 24$ & 84 & 17.9 \\
\hline & & & 37.5 \\
\hline & Illiterate(0) & 53 & 33.1 \\
\hline & Primary(1-5) & 111 & 11.5 \\
\hline & Secondary(6-10) & 98 & 45.6 \\
\hline & Higher( $\geq 11)$ & 34 & 54.4 \\
\hline & & & \\
\hline & Urban & 135 & 30.1 \\
\hline & Rural & 161 & 37.2 \\
\hline & & & 32.8 \\
\hline
\end{tabular}




\begin{tabular}{|c|c|c|c|}
\hline Number of surviving children & & & \\
\hline & $\leq 2$ & 154 & 52.0 \\
\hline Desired Number of Children & $\geq 3$ & 142 & 48.0 \\
\hline & & & 55.7 \\
\hline Sex preference & $\leq 2$ & 165 & 44.3 \\
\hline & & 131 & 86.1 \\
\hline Awareness regarding contraception & Yes & 265 & 13.9 \\
\hline & No & 41 & 55.7 \\
\hline & Yes & 165 & 44.3 \\
\hline Decision of family planning & & 131 & \\
\hline & Yes & & 56.8 \\
\hline & No & 168 & 43.2 \\
\hline & Total & 296 & 100.0 \\
\hline
\end{tabular}

Source: Authors' compilation, 2019

\section{Bivariate Analysis:}

Table 3: Information about Socio-economic Determinants affecting the family size.

\begin{tabular}{|c|c|c|c|c|c|}
\hline \multicolumn{2}{|c|}{ Variables } & \multicolumn{2}{|c|}{ Family size } & \multirow{2}{*}{$\begin{array}{c}\text { Test statistic } \\
\text { (df) }\end{array}$} & \multirow[t]{2}{*}{$P$ value } \\
\hline Age(In year) & & Small $(\leq 4)$ & Large $(\geq 5)$ & & \\
\hline & $\leq 30$ & $43.8 \%(70)$ & $34.6 \%(47)$ & & \\
\hline & $31-40$ & $36.3 \%(58)$ & $31.6 \%(43)$ & $7.364^{(2)}$ & $.025 * *$ \\
\hline & $\geq 41$ & $20.0 \%(32)$ & $33.8 \%(46)$ & & \\
\hline \multicolumn{6}{|c|}{ Educational Status } \\
\hline & Illiterate $(0)$ & $20.2 \%(19)$ & $16.8 \%(34)$ & & \\
\hline & primary(1-5) & $27.7 \%(26)$ & $42.1 \%(85)$ & $13.008^{(3)}$ & $.008 * *$ \\
\hline & secondary $(6-10)$ & $33.0 \%(31)$ & $33.2 \%(67)$ & & \\
\hline & higher( $\geq 11)$ & $19.1 \%(18)$ & $7.9 \%(16)$ & & \\
\hline \multicolumn{6}{|l|}{ Residence } \\
\hline & Urban & $52.5 \%(84)$ & $37.5 \%(51)$ & $6.668^{(1)}$ & $.010 * *$ \\
\hline & Rural & $47.5 \%(76)$ & $62.5 \%(85)$ & & \\
\hline \multicolumn{6}{|l|}{ Family Income } \\
\hline & $\leq 10000$ & $23.4 \%(41)$ & $27.7 \%(56)$ & & \\
\hline & $10001-20000$ & $33.0 \%(31)$ & $33.2 \%(67)$ & $7.628^{(2)}$ & $.022 * *$ \\
\hline & $\geq 20001$ & $23.4 \%((22)$ & $39.1 \%(79)$ & & \\
\hline \multicolumn{6}{|c|}{ Number of surviving children } \\
\hline & $\leq 2$ & $69.4 \%(111)$ & $31.6 \%(43)$ & $118.700^{(1)}$ & $\mathrm{P}<.000 * * *$ \\
\hline & $\geq 3$ & $30.6 \%(49)$ & $68.4 \%(93)$ & & \\
\hline \multicolumn{6}{|c|}{ Desired Number of Children } \\
\hline & $\leq 2$ & $70.0 \%(112)$ & $39.0 \%(53)$ & $49.899^{(1)}$ & $\mathrm{P}<.000 * * *$ \\
\hline & $\geq 3$ & $30.0 \%(48)$ & $61.0 \%(83)$ & & \\
\hline Sex preference & & Small (4>) & Large $(5<)$ & & \\
\hline & Yes & $81.3 \%(130)$ & $91.9 \%(125)$ & $7.003^{(1)}$ & $.008 * *$ \\
\hline & No & $18.8 \%(30)$ & $8.1 \%(11)$ & & \\
\hline \multicolumn{6}{|c|}{ Decision of family planning } \\
\hline & Yes & $65.6 \%(105)$ & $46.3 \%(63)$ & $11.159^{(1)}$ & $\mathrm{P}<.000 * *$ \\
\hline & No & $34.4 \%(55)$ & $53.7 \%(73)$ & & \\
\hline \multicolumn{6}{|c|}{$\begin{array}{c}\text { Awareness regarding } \\
\text { contraception }\end{array}$} \\
\hline & Yes & $63.1 \%(101)$ & $47.1 \%(64)$ & $17.415(1)$ & $\mathrm{P}<.000 * *$ \\
\hline & No & $36.9 \%(59)$ & $52.9 \%(72)$ & & \\
\hline
\end{tabular}

\section{Source: Authors' compilation, 2019}


The result reported in Table 3 reveals the sociodemographic features of the respondents and their impact on family size. The findings of chi-square tests clarify that respondents' age, Educational Status, residences, family income, number of survi- ving children, desired Number of Children, sex preferences, decision of family planning and Awareness regarding contraception are statistically significant $(p<0.05)$ among these variables associated with their family size determinants.

\section{OLS predicting Family size:}

Table 4: OLS Regression Analysis.

\begin{tabular}{|c|c|}
\hline \multicolumn{2}{|c|}{ OLS Models of Predictors of family size determinant } \\
\hline Independent Variable & Dependent Variable: Number of Family size \\
\hline & $\beta$ (S.E.) \\
\hline R-squared & $(.298)$ \\
\hline (Constant) & $3.40^{* *}$ \\
\hline Predictor & $.103(.013)$ \\
\hline Age & $-.008(.024)$ \\
\hline Age at first Marriage & $.054(.019)$ \\
\hline Educational Status of respondent & $.300^{* *}(.080)$ \\
\hline Number of living children & $.208^{* *}(.077)$ \\
\hline Desired number of children & $.000(.000)$ \\
\hline Monthly Household Income & $-.193 *(.000)$ \\
\hline Monthly Income of respondent & \\
\hline
\end{tabular}

\section{Source: Authors' compilation, 2019}

Table 4 helps us to evaluate the impact of socioeconomic factors impact on family size determinants of the respondents. The coefficient value of number living children is 0.300 which is significant at 1 percent significant level. This value implies that if other things remain same, increase in number of surviving children increase family size. A one unite incensement of number of living children will increase number of family member by 0.300 unit. Another important variable is desired number of children. The coefficient value for desired number of children is 0.208 . It implies that number of family member is positively related to desired number of children. A one percent increase in Desired of children can result in an increase of 0.208 percent increase in number of family member. Another important variable is monthly income of respondent. The coefficient value for monthly income of respondent is -0.193. It implies that number of family member is negative related to monthly income of respondent. A one percent increase in monthly income of respondent can result in a decrease of -0.193 percent decrease in number of family member. Furthermore, R2 value of 0.298 implies that almost 30 percent variation in explained variable family size determinant is clarified by the measured explanatory variables. In conclusion, OLS regression tells us that number of family member and living children, and desired children are positive impact on it. Besides, monthly respondent income has negative influence on family size determinant.

\section{DISCUSSION:}

Family size in a particular society depends on marriage, family composition, and adoption norms. It also depends upon socioeconomic and cultural forces. Family, the basic unit of society, the world has been undergoing many fundamental changes and profound transformation due to comprehensive socioeconomic development and technological advancement. It is significant in this connection that both in developed and developing countries including Bangladesh, the average family size is decreased, because in many cases young people are getting married at a later age (Samad, 2015). The key motive of the study is to explore the determinants related to the family size of households in the Khulna district of Bangladesh. Other objectives of this study were to sort out the nature and limit of family size among the household. Starting from the 
general or main objective, this study was designed to explore the factors that determine family size among the participants.

The findings of the study reveal that a smaller number of family sizes among the participants of 30 to 18 age groups 51.1 percent which years which five of every ten. In line with these findings, (McCarthy \& Oni, 1987; Kabir et al., 1994) showed that the age of the participants is to be associated with family size determinant. They found that younger women with fewer children prefer smaller families and women with more children prefer larger families. The results of this study present that age at first marriage for both men and women have not found to be associated with the family size determines. This result is consistent with the previous study (Campbells, 1986), which reported that age at first marriage for both men and women have not found to be related to the preferred family size determines. But, age at first marriage has a positive effect on choosing family size determines (Sharif et al., 2007; Dibaba \& Mitike, 2016).

The study presents that the majority of the respondents 41.2 percent receive the primary level of education which is more influencing for a large number of family size (Caldwell, 1980). This finding is also consistent with (Kpakpor, 2005; Dibaba \& Mitike, 2016) that states that people who attained a secondary and higher level of education was found to be 2 and 2.6 times more likely to prefer small family size compared to people who had no education. In the study residences of the respondents were remarkable associated with their family size determinant and it is consistent with the findings of previous studies (Ali, 1989; Uddin et al., 2011) that indicated that partici-pation from rural had a greater number of both mean number of CEB and large family size than those from urban areas.

Findings depict statistics also reveal that monthly household income is significantly linked with great influences in family size. Previous studies also approved that large families are also very much affected by the family's monthly income and these studies showed that the idea of higher-income of family influences small family size than large family which is supported by (Becker, 1991; Sharif et al., 2007).
The numbers of living children were significantly similar with small family size among the respondents. In this study it is seen that where the number of living children is low, then small family size tendency must be high which is consistent with the result of another study (Kabir et al., 1994) that also found the case of the additional children for the women having a certain number of living children with no living sons or with one or more living sons to influence family size. Findings of the study show that the participants ( 86.2 percent) who have desired little number of children, the tendency of their family sizes is relatively small and it has similarity with (Campbells, 1986).

In this study, the highest of the respondents' 92.6 percent who were preferred with sex among them hold large family size that family size determinant is positively correlated with sex preferences (boy or girl) and it was consistent with the outcome of a previous study (Adeokun, 1979) explained that A strong sex preference which is on getting more sons than daughters to be associated with the determining family size. Similarly, other studies (Egero \& Hammarskjold, 1994; Nag, 1991) showed that son preference was found to have a continuing influence on large family size.

The study reveals that the majority of the participants $(80.9 \%)$ who have used any form of contraceptive generally have small family sizes compared with the participants (19.1 percent) who have not used contraceptive and it is consistent with the findings of previous study (Maleche, 1990) that also shows that people who desired a small family size continue to use contraception. This study depicts that participant (78.7 percent) who has a decision of family planning generally the inclination of small family. This result is consistent with another study which showed that when the decision of family planning is high then large family size likely to must be low (Siddiq, 1997). This study depicts that there was a significant influence on awareness regarding contraception before sexual engagement.

Conclusions from findings reveal that, various determinants such as the respondents' age, educational status, spouse's educational status and respondents' residence, occupation, family income, number of living children and desired number of children, sex preferences, use of contraceptive, 
decision of family planning and awareness regarding contraception before sexual engagement were remarkable linked with family size determinant. On the contrary, there is no significant relationship between the respondents' religion and age at marriage.

\section{CONCLUSION:}

Family, the simple unit of society, in world has been undergoing many essential changes and profound transformation. Family size determines to a larger extent the economic background of the populace. The major factors affecting changes in the family pattern of Bangladesh were the expansion of educational and employment opportunities. The present study, conducted in Khulna indicates that different socio-demographic and economic factors such as age, education, number of surviving children, a desired number of children, residences, occupation, and family income are associated with the family size determinant. Besides, some cultural factors such as sex preferences, use of contraceptives, the decision of family planning and awareness regarding contraception before sexual engagement effect of family size determinant. The study reveals that it is evident that most families this study area have small family sizes. Besides, respondents with some form of higher education have smaller family sizes hence having educated their children well. Respondents with smaller family sizes were also seen enjoying better social and economic life as compared to their counterparts with relatively large family sizes (Sarker, 1997; Gereziher and Shiferaw, 2020). However, the government policymakers and social workers are working to motivate people to have small families. It is also recommended that more educational campaigns and contraceptive usage should be launched the Bangladesh Health Service and Schools on the potentials of either boys or girls in the family.

\section{ACKNOWLEDGEMENT:}

The researcher greatly obliged his supervisor, Shaharior Rahman Razu, Assistant Professor, Sociology Discipline, Khulna University for his kind supervision, intellectual motivation, valuable advice and continuous guidance. The researcher would not be able to accomplish this paper without his careful readings of many drafts, rapid and practical feedback, and guidance that he provided. Alongside, The researcher also grateful to all his teachers of sociology discipline who have supported his by their advices and guidance many times in his study period.

\section{CONFLICT OF INTERESTS:}

The researcher declares no possible conflict of interest concerning the study, data collection \& analysis, authorship, and/or publication of this present article.

\section{REFERENCES:}

1. Adeokun, L. A. (1979). Male attitude to birth control and family planning: National survey of fertility, family and planning. Demographic Social Survey Monograph: University of Ife, 1, 105-125.

2. Aigbokhan, B. E. (2008). Growth, inequality and poverty in Nigeria. Addis Ababa, Ethiopia: United Nations Economic Commission for Africa Press, 3(3), 33. http://hdl.handle.net/10855/14927

3. Ali, S. M. (1989). Determinants of family size preferences in Pakistan. Pakistan Institute of Development Economics, 28(3), 207-231.

https://ideas.repec.org/a/pid/journl/v28y1989i3 p207-232.html

4. Arnold, F. (1985). Measuring the effect of sex preference on fertility: the case of Korea. Journal of Social Demography, 22, 280. https://doi.org/10.2307/2061182

5. Arnold, F. (1987). The Effect of sex preference on fertility and family planning: Empirical Evidence. Journal of Population Bulletin, 44(23-24): 44-55.

https://europepmc.org/article/med/12315521

6. Arnold, F. (1991). Sex preference for children and its demographic and health implications. Journal of Demographical Health Surveys World Conference, 1, 249.

7. Arthur, J. L. (2005). Family size and its socio-economic implications in the sunyani municipality of the brong ahafo region of Ghana, West Africa. Journal of Social Sciences, Pp. 1-59. http://www.ciesin.org/documents/arthurjl.pdf

8. Arthur, A. C. (2009). The Impact of development control systems on land use in Sunyani, A special study submitted to the 
Department of Planning Kwame Nkrumah University of Science and Technology, Journal of Science in Planning, 12(2).

9. Becker, G. S. (1991). Interaction Between Quality and Quantity of Children. Journal of Political Economy, 82(2), 279-288.

10. Bhargava, A. (2007). Desired family size, family planning and fertility in Ethiopia. Journal of Biology and Social Sciences, 39(2), 367-381. https://doi.org/10.1017/s0021932006001593

11. Caldwell, J. C. (1980). Mass Education as a Determinant of the Timing of Fertility Decline in Kenya. Journal of Population and Development Review, 6(2), 225-255.

12. Campbells, E. K. (1986). Male role in fertility decision making in Robert sport, Liberia: an experimental exercise for policy formul-ation. Janasamkhya, 4, 41. https://pubmed.ncbi.nlm.nih.gov/12268797/

13. Cleland, J., Verral, J., \& Vaessen, M. (1983). Preference for sex of children and their influence on reproductive behavior: WFS comparative studies, cross-National summaries. J. of International Statistical Institute, 27.

14. Dibaba, B., \& Mitike, G. (2016). Factors influencing desired family size among residents of Assela Town. Journal of Women's Health Care, 5(6), 342. https://doi.org/10.4172/2167-0420.1000342

15. Egero, B., \& Hammarskjold, M. (1994). Kenya: Reproductive change strain. In B. Egero, \& E. K. Mburugu, Understanding Reproductive Change: Kenya, Tamil Nadu, Punjab. Costa Rica: Lund university Press, pp.31-64.

16. Gereziher, B. and Shiferaw Y. (2020). Corporate social responsibility practice of multinational companies in Ethiopia: a case study of Heineken Brewery S.C, Br. J. Arts Humanit., 2(2), 36-55. https://doi.org/10.34104/bjah.020036055

17. Hagen, C. A., Fikree, F. F., Sherali, A., \& Hoodbhoy, F. (1999). Fertility and family planning trends in Karachi, Pakistan. International Fam Plan Perspect, 25(1), 38-43. https://www.guttmacher.org/journals/ipsrh/199 9/03/fertility-and-family-planning-trends-kara chi-pakistan
18. Hyeladi, A., \& Alfred, J. (2014). Assessment of family sizes and poverty levels in Mangu LGA, Plateau State. International Journal of Humanities and Social Science, 4(3), 310314. http://www.ijhssnet.com/journals/Vol_4_No_3 February_2014/31.pdf

19. Jones, L., \& Arthur. (2005). Family size and its socio-economic implications in the Sunyani Municipality of the Brong Ahafo Region of Ghana. West Africa: Center for development Studies, Ghana.

20. Kabir, M., Amin, R., Ahmed, A. U., \& Chowdhury, J. (1994). Factors affecting desired family size in Bangladesh. Journal of Biology and Social Sciences, 26, 369-375. https://doi.org/10.1017/s0021932000021441

21. Koenig, M. A., Phillips, J. F., Simmons , R. S., \& Khan, M. A. (2013). Trends in family size preferences and contraceptive use in Matlab, Bangladesh: Stud Fam. Journal of Women's Health Care, 18, 117-1127.

22. Kpakpor, M. (2005). Nigeria to Eradicate Poverty by 2010. Nigeria: The Nigerian Tribune, October 16, Pp. 7. http://www.ijhssnet.com/journals/Vol_4_No_3 February 2014/31.pdf

23. Maleche, R. (1990). Accessibility and contraceptive use in Kenya: Post Grad, Dip, in Population Studies (Vol. 3). Nairobi: University of Nairobi. Corpus ID: 55070006.

24. Maloney, C., Aziz, K. M., \& Sarker, P. C. (1981). Beliefs and fertility in Bangladesh. Dacca: International Centre for Diarrhoeal Disease research, Bangladesh., 31(3).

25. McCarthy, J., \& Oni, G. A. (1987, May ). Desired family size and its determinants among urban Nigerian women: A two-stage analysis. Journal of Demography, 24(2), 279-290.

https://link.springer.com/article/10.2307/20616 $\underline{35}$

26. Nag, M. (1991). Sex preference in Bangladesh, India and Pakistan and its effect on fertility. Journal of Population Council, 27, 369-375.

27. Ojha, A. (1999). Family welfare programme in India under target setting and target free approaches: Heal Popul Perspect. Journal of Biology and Social Sciences, 22, 68-75. 
28. Parvez MS, Rahaman MA, Fatema K, and Mondal DR. (2019). Impact of social networking sites on the interpersonal relationship among teenager: a sociological analysis in the district of Bagerhat. Br. J. Arts Humanit., 1(5), 14-27. https://doi.org/10.34104/bjah.019.1427

29. Samad, M. (2015). Marriage in changing family pattern of Bangladesh: The Present Trends. International Journal of Social Work and Human Services Practice, 3(5), 155-161.

http://www.hrpub.org/download/20151130/IJR H4-19290354.pdf

30. Sarker, P. C. (1997). Social structure and fertility behavior. Dhaka: Centre for Development Services, 12-53.

31. Sharif, M., Mubeen, C., \& Hussian, S. (2007). Factors affecting family size and sex preference: A Study of Urban Tehsil Fasialabad (Pakistan). Journal of Agricutltral Sociaol Science, 3(1), 25-27. http://www.fspublishers.org/published_papers/ 29017 ..pdf
32. Siddiq, S. M. (1997). "A sociological study of contraceptive use and reproductive behaviour of selected married males in rural communities". Journal of Rural Sociology, 4(6), 142-143.

33. Uddin, M. I., Bhuyan, K. C., \& Islam, S. S. (2011). Determinants of desired family size and children ever born in Bangladesh. The Journal of Family Welfare, 57(2), 39-47. https://pdfs.semanticscholar.org/691c/b7d5838 549e6385c977f49b8d15c3c85e629.pdf

34. Uddin, M. E., Habib, T. Z., \& Akter, M. S. (2012). Socio-cultural factors affecting family size between muslim and santal communities in rural Bangladesh. Journal of Anthropology, 8(2), 395-410.

35. Walle, E. (1992). Fertility transition, conscious choice, and numeracy. Journal of Demography, 29, 487-502.

https://link.springer.com/article/10.2307/20618 $\underline{48}$

Citation: Islam MJ. (2020). Factors influencing family size: a critical study on Khulna district of Bangladesh, Br. J. Arts Humanit., 2(4), 73-81. https://doi.org/10.34104/bjah.020073081 @) 